Vol. 11, No. 4 (Apr., 1896), pp. 97-102

\title{
MODERN LANGUAGE NOTES.
}

\begin{tabular}{c} 
Baltimore, April, 1896. \\
\hline The Romaunt of the Rose: ADDI- \\
TIONAL EVIDENCE THAT IT IS \\
CHAUCER'S.
\end{tabular}

THERE are five poems included in modern editions of Chaucer's works that are now generally recognized as not his. These are The Cuckoo and the Nightingale, The Complaint of a Lover's Life, The Flower and the Leaf, The Court of Love, and Chaucer's Dream. One other long work, the English version of the famous French poem of the thirteenth century, Le Roman de la Rose, which has come down to us as translated by Chaucer, is now the subject of much dispute.

Professor Skeat has inserted an essay in his third edition of the Prioresses Tale in which he proves to his satisfaction that this poem cannot be Chaucer's, reasserting this opinion, with some modifications, in his recent edition of Chaucer's complete works. He rests his proof mainly on internal, philological grounds, relating to the vocabulary, to the dialect, to the grammar, and to the rime. To speak exactly, he originally proposed seven tests of this nature, but he has since laid less stress upon some of them, and, following certain German scholars, so modified his opinions as to admit that a short portion of the translation at the beginning may have been and probably was Chaucer's. He still claims, however, that as concerns the remainder, the main body of the translation, his tests hold good.

In his Studies in Chancer, Professor Lounsbury has explained and refuted these tests at the length of more than one hundred and fifty pages. A discussion, either of the tests or of the arguments against them, is not necessary here. One, for example, the "dialect test," upon which Skeat lays particular stress, which he asserts would "alone prove decisive," is shown by Lounsbury to point if anything to a Chaucerian authorship. This is the test arguing from the presence of Northern forms like participles in -and, from the use of til for to, and similarly, in the translated poem. Because these Northern forms, when found, are essential to the rime and hence in no way chargeable to the scribe, it is the judgment of Skeat that the translator wrote, not in the East Midland dialect, like Chaucer, but in the dialect of the North. If this were a fair statement of the case, the presence of these forms might prove significant, but it is not. If there is a sprinkling of Northern forms in the translation, there is also a sprinkling of Southern. The employment of both is exceptional, and in grammatical peculiarities, such as the verb-ending in the third singular present, the dialect regularly employed is unquestionably the Midland. To quote summarizingly from Professor Lounsbury: When you consider that in the 7700 lines of the poem, there are no more than a possible five cases of the participle in -and, which Skeat would lead you to suppose the usual form, and scores and scores of cases of the Midland participle in -ing, you see which way the test really points: Because the -and words are used as rhyme words shows why they are used at all, for the -ing ending would in such cases afford no rime. Add the consideration that this -and ending is to be found frequently in manuscripts of poems unquestionably Chaucer's, and you have the matter fairly stated.

This and Skeat's remaining tests thus examined, and all, unless it be the test based on rime and meter, adequately explained, Professor Lounsbury relies mainly for his belief that the translation is Chaucer's on a quantity of positive evidence drawn from matters of style, from parallelisms in language and expression, in uses of words and modes of thought. Whatever may be thought of these parallelisms, which may themselves be paralleled from the works of Gower, or from other poems of the time, or whatever may be the attitude of students towards the genuineness of the translation, Professor Lounsbury has put forth a strong array of arguments, and believes he has shown that henceforth the burden of proof should rest as much with those who deny Chaucerian authorship as with those who affirm it. It must always be renembered, to quote a last time from his discussion, that though there may seem to be 
difficulties in the way of the translation's being Chaucer's, there are much greater difficulties in the way of its not being Chaucer's.

There remain other tests which it may be interesting to apply, the tests of sentencelength and sentence-structure. It is not claimed that the results shown by the application of these tests should be necessarly conclusive; they will be left to stand on their own merits. But it is obvious that comparisons of the sets of figures here presented, calculated from Chaucer's genuine writings, from those unquestionably spurious, from the English version of the Romaunt of the Rose and from the French original, should throw some light upon the question, either on one side or on the other. It is also obvious that such testimony should have equal weight with that resting on vague theorizing or speculations, or on the uncertain foundations of personal opinion.

A few words in explanation of the tables presented. Throughout in making calculations, a uniform system of punctuation has been adopted in the poems investigated. Any rigorously uniform system would have served the purpose, since it is the relative results, rather than the results in themselves, that are important. Using Skeat's edition of Chaucer, I preferred to adopt and carry out consistently his system of punctuation as shown in his edition of the Prologue (Clarendon Press, ISgr), reprinted without change in his six volume edition of 1894 . Skeat had nothing in view depending for the value of its demonstration on the uniformity of his punctuation, and hence does not always carry out his own principles, varying sometimes within the same poem, sometimes between different poems. In such cases I have repunctuated to render the whole uniform. In the 858 lines of the Prologue, some twenty changes were made, carrying out his principle of ending one sentence and beginning another wherever the sense seemed grammatically complete. Thus in the following:

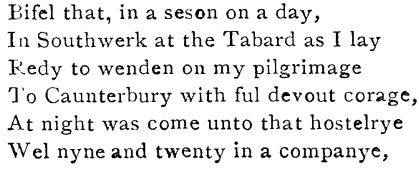

Of sondry folk, by aventure y-falle

In felawshipe, and pilgrims were they alle, That towards Caunterbury wolden ryde; The chambres and the stables weren wyde, And wel we weren esed atte beste,

the semicolon after ryde was altered to a period.

The other poenıs examined were punctuated in the same manner and made uniform with the Prologue.

Wherever a sentence is defective in form, that is, without a predicate as in, "But now to purpose" (Legend of Lucretia), or "Lo here a deed of man and that a right" (Legend of Philomela), it has been omitted from the number of simple sentences, although included in the calculations in other respects. Expressions like thabsence or my self are treated in accordance with their present forms. In the case of hyphenated words, both parts of the compound are counted separately.

In presenting the results shown in these tables as in any way significant, I am presuming upon two facts already amply demonstrated, the constancy of sentence-lengths in authors (L. A. Sherman, "Some Observations upon the Sentence-Length in English Prose," University Studies, published by the University of Nebraska, Vol., i, No. ii, and "On Certain Facts and Principles in the Development of Form in Literature," Vol. i, No. iv), and the constancy of predication averages in authors (G. W. Gerwig, "On the Decrease of Predication and of Sentence-Weight in English Prose," University Studies, Vol. ii, No. i). It is not claimed that any particular deductions can be made from the other figures presented, for their value has not yet been investigated. They are included only for completeness in the analysis of the style and sentence-structure of the poems examined.

Investigations in Chaucer's recognized writings show the following: 


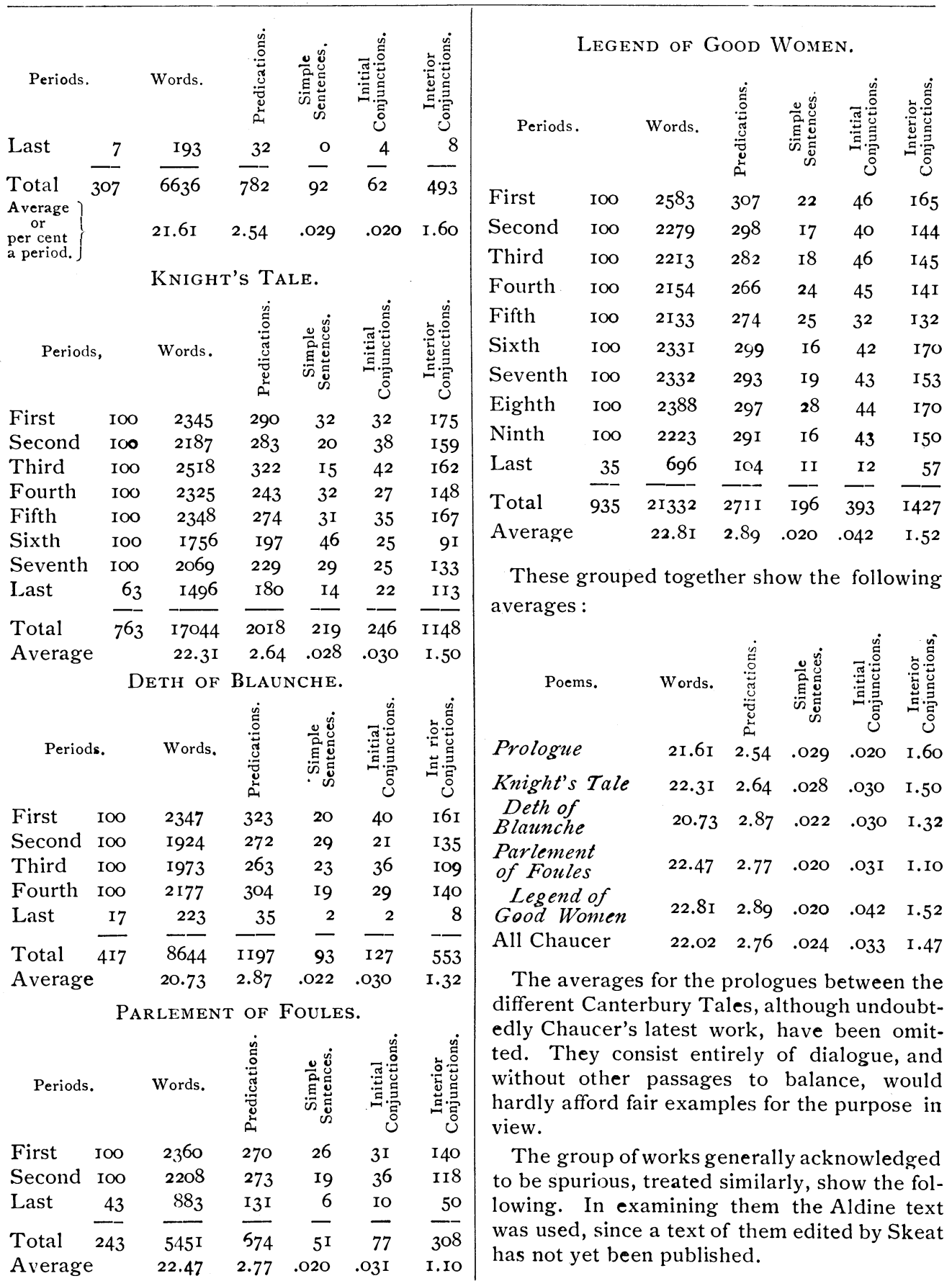


Flower and Leaf.

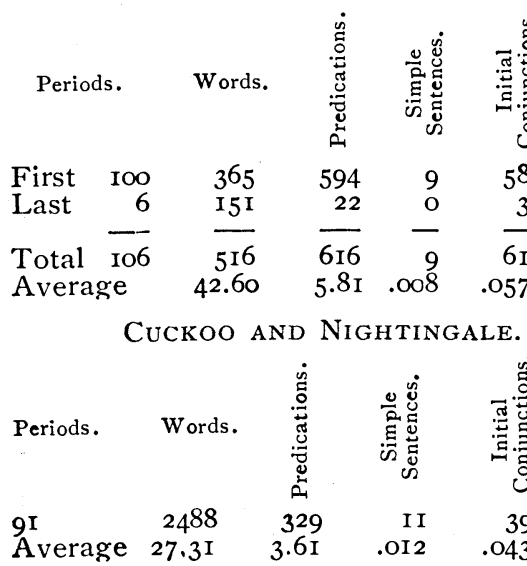

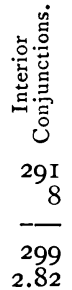

Complaint of a Lover's Life.

\begin{tabular}{|c|c|c|c|c|c|c|}
\hline Periods. & & Words. & 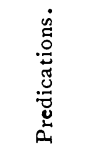 & 总 & 离 & . \\
\hline First & 100 & $35^{69}$ & 330 & 22 & 46 & \\
\hline & 40 & I $50 \mathrm{I}$ & 59 & 5 & & \\
\hline $\begin{array}{l}\text { I } \\
\text { Iverage }\end{array}$ & $e^{\overline{I 40}}$ & $\begin{array}{r}5070 \\
36.21\end{array}$ & $\begin{array}{r}489 \\
3.49\end{array}$ & $\begin{array}{r}27 \\
.018\end{array}$ & $\begin{array}{r}72 \\
05 \mathrm{I}\end{array}$ & $\begin{array}{l}32 \\
.2\end{array}$ \\
\hline Periods. & & Court & 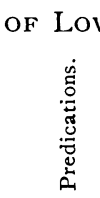 & 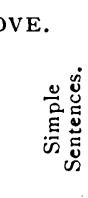 & 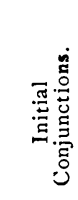 & 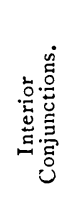 \\
\hline $\begin{array}{l}\text { First } \\
\text { Second } \\
\text { Third } \\
\text { Fourth } \\
\text { Last }\end{array}$ & $\begin{array}{r}100 \\
100 \\
100 \\
100 \\
63\end{array}$ & $\begin{array}{l}2627 \\
2724 \\
2388 \\
2157 \\
1556\end{array}$ & $\begin{array}{l}289 \\
305 \\
297 \\
320 \\
218\end{array}$ & $\begin{array}{l}23 \\
21 \\
\text { I } 8 \\
16 \\
\text { II }\end{array}$ & $\begin{array}{l}25 \\
16\end{array}$ & 85 \\
\hline $\begin{array}{l}\text { Total } \\
\text { Average }\end{array}$ & $\overline{463}$ & $\begin{array}{l}\text { I I } 45^{2} \\
24.73\end{array}$ & $\begin{array}{r}1429 \\
3.080\end{array}$ & $\begin{array}{l}89 \\
.09\end{array}$ & $\begin{array}{r}128 \\
.027\end{array}$ & .98 \\
\hline Periods. & & Chaucer & 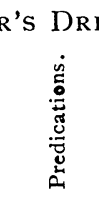 & EAM. & 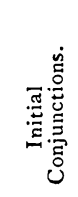 & 总 \\
\hline $\begin{array}{l}\text { First } \\
\text { Second } \\
\text { Last }\end{array}$ & $\begin{array}{r}100 \\
100 \\
73\end{array}$ & $\begin{array}{l}5033 \\
5575 \\
3935\end{array}$ & $\begin{array}{l}657 \\
7 \mathrm{OI} \\
44 \mathrm{I}\end{array}$ & $\begin{array}{l}3 \\
8 \\
\text { I }\end{array}$ & $\begin{array}{l}40 \\
40 \\
37\end{array}$ & $\begin{array}{l}42 \\
48 \\
37\end{array}$ \\
\hline $\begin{array}{l}\text { Total } \\
\text { Average }\end{array}$ & 273 & 53.27 & $\begin{array}{l}1799 \\
6.58\end{array}$ & $\begin{array}{r}\text { I2 } \\
.004\end{array}$ & $\begin{array}{r}\text { II } 7 \\
.042\end{array}$ & 1 \\
\hline
\end{tabular}

Grouped together, these show the following sentence averages :

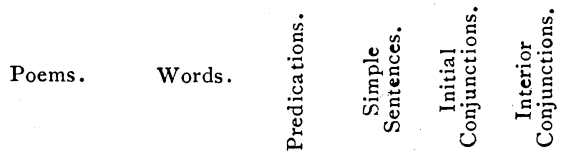

Flower and Leaf $42.60 \quad 5.8 \mathrm{I} \quad .008 \quad 057 \quad 2.82$ Cuckoo and $\begin{array}{llllll}\text { Nightingale } & 27.31 & 3.61 & \text {.0I2 } & \text {.043 } & 2.12\end{array}$ $\begin{array}{llllll}\text { Complaint of } a & 36.21 & 3.49 & \text {.0I9 } & .05 \mathrm{I} & 2.29\end{array}$ $\begin{array}{lllllll}\text { Court of love } & 24.73 & 3.08 & .019 & .027 & 1.98\end{array}$ $\begin{array}{llllll}\text { Chaucer's Dream } 53.27 & 6.58 & .004 & .042 & 4.69\end{array}$

These are substantially the results one would look for. The averages vary as one would expect in poems coming from different authors. What is to be noted is that none agree with the averages of Chaucer, the discrepancies being especially marked in the case of predications and sentence-lengths. Where Chaucer shows an average of two and a fraction verbs a sentence, these Prems show three and over. The Court of Love comes nearer than any of the others to the sentence-length of Chaucer, but shows an average of nearly twenty-five words a sentence, which Chaucer does not reach. The fact that this poem should fall so low even as 24.73 is to be explained by the presence in it of more than the usual quantity of dialogue or broken sentences, and, especially, by the fact that it is probably, as proved by its grammatical forms, the product of later than the fourteenth century (Lounsbury, Studies in Chaucer, Vol. i.).

Now to see with which of these two groups belongs the Romaunt of the Rose.

Romaunt of THE Rose.

First

Second

Third

Fourth

Fifth

Sixth

Seventh

Eighth

Ninth

\begin{tabular}{|c|c|c|c|c|c|c|}
\hline Periods. & & Words. & 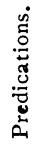 & ह & & 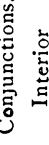 \\
\hline & 100 & $235 \mathrm{I}$ & 304 & 22 & 3 & 2 \\
\hline & 100 & $24 \mathrm{I} 7$ & 303 & 22 & 3 & 5 \\
\hline & 100 & I 747 & I95 & 40 & & 9 \\
\hline & 100 & I89o & 234 & 29 & 3 & 5 \\
\hline & 100 & 2219 & 263 & I8 & 4 & 7 \\
\hline & 100 & 2080 & $25 \mathrm{I}$ & 20 & 5 & o \\
\hline & 100 & 2169 & 308 & I 5 & 3 & 7 \\
\hline & 100 & 2015 & 275 & I7 & 4 & I \\
\hline & roo & 2239 & $28 \mathrm{I}$ & 20 & & \\
\hline
\end{tabular}


Periods.

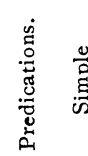

Tenth

Eleventh

Twelfth

Thirteenth

Fourteenth

Fifteenth

Sixteenth

Seventeenth

Eighteenth

Nineteenth

Twentieth

Twenty-first

Twenty-second

Last

Total

Averages

This brings us to a final table of comparison.

Chaucer and the Romaunt of the Rose.

Periods. Words.

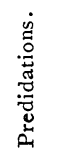

$$
\text { 部苍 }
$$

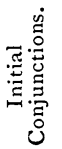

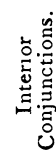

Chaucer,

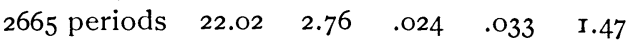

Romaunt,

2205 periods $\quad 21.93 \quad 2.88 \quad .020 \quad .030 \quad 1.49$

The figures presented in this last table seem significant. The average sentencelength for Chaucer is 22.02, for the Romaunt of the Rose 21.93, a remarkably close correspondence. The Romaunt shows 2.88 predications and $\mathrm{I} .49$ interior conjunctions, Chaucer 2.76 predications and $\mathrm{I} .47$ interior conjunctions a sentence. The agreement is the same with the initial conjunctions, and close with the simple sentences, where the correspondence, that in predications and sentencelength excepted, has most significance. Not only does the Romaunt of the Rose fail to show any of the variation from Chaucer's manner, demonstrated in the other poems long attributed to him but now rejected, but it seems to stand on the same literary footing as those which are Chaucer's beyond dispute. The use of some other text of Chaucer's poems, or the adoption of some other system of punctuation might make changes in the exact figures presented, but could make no change in the relative results.

As elsewhere mentioned, following certain German scholars, Skeat has recently modified his sweeping assertion of the spuriousness of the translation so far as to admit that a small portion at the beginning, which he designates Fragment A, was probably the work of Chaucer. The remainder of the poem he divides into two other fragments, $\mathrm{B}$ and $\mathrm{C}$, which he declares not of Chaucerian authorship, and by two different hands. A re-arranging of the figures given, according to this theory shows:

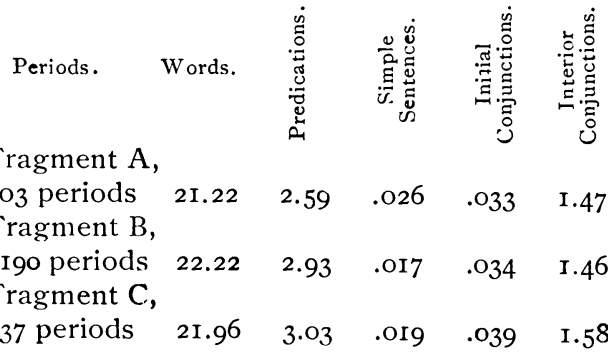

Variation is shown, but no more than normal; no more, for instance, than in Chaucer's recognized works. One has only to compare these sets of figures with those in the group of spurious works, really the works of different hands, to show that no color is lent to the fragment theory, but the contrary. It may even be wondered that the variation is not more, for the translation of so long a poem as Le Roman de la Rose, or eveu of a fraction of it, could not have been consecutive work. It must have extended over a long period of Chaucer's life, and before its completion have seen many changes of mood and mannerisms that would naturally affect its style.

The sentence-length test is that which deserves particular stress. It has been shown by Professor Sherman that in prose Chaucer wrote a shorter sentence than any of his contemporaries. The same seems to be true of his poetry. Skeat has said that Lydgate is the real author of the Complaint of a Lover's Life, which shows an average of about thirty- 
six words a sentence. Five hundred periods of Gower show an average of thirty-two.

Gower, Confessio Amantis, Book i.

\begin{tabular}{|c|c|c|c|c|}
\hline First & Hund & eriods & Average & $3 \mathrm{I} \cdot \mathrm{I} 3$ \\
\hline Second & " & “" & “" & $3 \mathrm{I} .47$ \\
\hline Third & "“ & “" & “" & $35.4 \mathrm{O}$ \\
\hline ourth & " & " & “" & $35 \cdot 36$ \\
\hline th & “" & “ & “" & 0.55 \\
\hline & “" & "General & “" & 32.78 \\
\hline
\end{tabular}

The sentence-length test verifies and would point, even were no other proofs at hand, to the conclusion that the five works classed as spurious could not be Chaucer's. The same test seems to point just as plainly to the Romaunt of the Rose as Chaucer's. Add the correspondence in the number of predications, simple sentences, and conjunctions, and the matter gains increased conclusiveness.

To make the demonstration complete, notice how the figures of the French original compare with those of the translation. Of course if the English version were a literal, word for word, line for line rendering, it is obvious enough that no value should be attached to its sentence-averages, as they would be governed by those of the original. But it is well known that the English poem, though it follows the French with reasonable closeness, is not really a translation but a paraphrase. In many places it expands the idea contained in the original; in many places it condenses or omits it. Sometimes the forms of expression or the language used, owe nothing to the French save bare suggestion. Again there is transposition or inversion. One would not expect, then, the sentence-length to be ruled by that of the original, or to be identical with it. As a matter of fact, it is not, as will be readily seen.

Le Roman de la Rose, Part i. Guillaume de Lorris.

\begin{tabular}{|c|c|c|c|c|}
\hline First $\mathrm{H}$ & . & eriods & Average & I9.95 \\
\hline Second & " & " & “ & 21.05 \\
\hline Third & " & “ & “" & I5.90 \\
\hline Fourth & “ & “" & “" & I $7 \cdot 34$ \\
\hline Fifth & “ & “" & " & 23.64 \\
\hline Sixth & “ & " & “" & 18.42 \\
\hline Seventh & " & " & “ & I9. IO \\
\hline Eighth & " & " & " & I8.7I \\
\hline Ninth & “ & “ & " & I9. \\
\hline
\end{tabular}

Tenth Hundred Periods

Eleventh " " "

Twelfth " ،

Remaining 34

Total I 234

6

“ “

From this it is plain that the sentence-length of the English version is the sentence-length of the translator, not of Guillaume de Lorris. Hence the sentence-length of the translator may be compared justly enough with Chaucer's a verages or with the a verages in the poems known not to he genuine. This was, perhaps, evident enough $\mathrm{l}_{1}$ already, for, as said elsewhere, the translation is not so much a translation as a paraphrase, closely following the original and equalling it in literary merit, but not literally rendering it. Still, additional evidence is not to be disregarded. As was to be expected, the difference of the English from the French is one of expaninsion.

The short sentence-length of the French is to be noted, Guillaume de Lorris showing two or three words less a sentence than Chaucer, who nevertheless wrote a shorter sentence than any Englishman of his time. It is to be doubted whether the French ever wrote so ponderously as did the English at this period. The subject yet remains to be investigated, but if De Lorris be a fair example, the sentencesense in French literature was then further developed than it was in English for some centuries.

In conclusion, it would seem that henceforward it is for those who pronounce the translation spurious to prove their position, not for those who believe it genuine. It is within the bounds of possibility that some one else may have had the same sentence averages as Chaucer; but such a supposition is far from probable, and until such an individual is produced, the results presented here should seem decisive. It is remarkable enough that there should have been one author who was to stand ahead of his contemporaries so far as Chaucer. That there should have been two, and that the name of the second should not have survived, seems more than we should be asked to believe.

\section{Lourse Pound.}

University of Nebraska. 